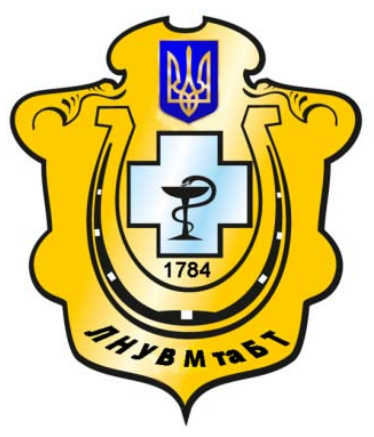

Науковий вісник Львівського національного університету ветеринарної медицини та біотехнологій імені С.3. Гжицького

Scientific Messenger of Lviv National University of Veterinary Medicine and Biotechnologies named after S.Z. Gzhytskyj

doi:10.15421/nvlvet6605

ISSN 2413-5550 print

ISSN 2518-1327 online

$\underline{\text { http://nvlvet.com.ua/ }}$

УДК 619:632.938:616.993.192.1(0.044)

\title{
Відносні показники імунограм у серопозитивних на токсоплазмену інвазію собак та котів
}

\author{
М.М. Брошков ${ }^{1}$, В.О. Трокоз ${ }^{2}$, А.А. Шевякова ${ }^{1}$ \\ dolinavet@gmail.com \\ ${ }^{1}$ Одеський державний аграрний університет, \\ вул. Пантелеймонівська, 13, м. Одеса, 65012, Украӥна \\ ${ }^{2}$ Національний університет біоресурсів і природокористування України, \\ вул. Героїв Оборони, 11, м. Київ, 03041, Украӥна
}

\begin{abstract}
В більшості паразитарних захворювань основною ланкою захисту організму є клітинний імунітет. Саме від його імунологічної реактивності залежить здатність організму адекватно відреагувати на введення антигену. Очінка відносних показників імунограм серопозитивних собак і котів показала, щьо більш виражене зменшення відносної кількості лімфоцитів в дослідній групі, відмічено у собак (на $33 \%$ в дослідній) в порівняні з котами (на 22\%). Така видова відмінність можливо пов'язана з ииклом розвитку самого збудника і тим, а саме, собаки є кінцевими господарями на відміну від котів. Порівнюючи відносну кількість Т-хелперних лімфоцитів, слід зазначити, щуо у серопозитивних собак цей показник був вищим (на 15\% в порівнянні з контролем) а у серопозитивних котів навпаки відмічено його зменшення (на 47\% в порівнянні з контролем). У дослідних собак порівняно з контролем здатність нейтрофілів до фагоиитозу менше на 8\%, а котів різниця складає $1,5 \%$.

Ключові слова: імунітет, токсоплазми Т-лімфоцити, В-лімфоччити, коти, собаки.
\end{abstract}

\section{Относительные показатели иммунограмм у сероположительных на токсоплазмену инвазию собак и кошек}

\author{
М.М. Брошков ${ }^{1}$, В.А. Трокоз ${ }^{2}$, А.А. Шевякова ${ }^{1}$ \\ dolinavet@gmail.com \\ ${ }^{1}$ Одесский государственный аграрный университет, \\ ул. Пантелеймоновская, 13, г. Одесса, 65012, Украина \\ ${ }^{2}$ Национальный университет биоресурсов и природопользования Украины, г. Киев, Украина \\ ул. Героев Оборонь, 11, Киев, 03041, Украина
}

\begin{abstract}
В большинстве паразитарных заболеваний основным звеном защиты организма является клеточный иммунитет. Именно от его иммунологической реактивности зависит способность организма адекватно отреагировать на введение антигена. Оченка относительных показателей иммунограмм серопозитивных собак и комек показала, что более выраженное уменьшение относительного количества лимфоцитов в опытной группе отмечено у собак (на $33 \%$ в опытной) в сравнении с котами (на 22\%). Такое видовое различие возможно связано с ииклом развития самого возбудителя и тем, а именно, собаки являются конечными хозяевами в отличие от котов. Сравнивая относительное количество T-хелперных лимфоцитов, следует отметить, что у серопозитивных собак этот показатель был выше (на 15\% в сравнении с контролем) а в сер опозитивних котов наоборот отмечено его уменьшение (на 47\% в сравнении с контролем). В опытных собак по сравнению с контролем способность нейтрофилов к фагоцитозу меньше на $8 \%$ а котов разница составляет $1,5 \%$.

Ключевые слова: иммунитет, токсоплазмы Т-лимфочиты, В-лимфочиты, коты, собаки.
\end{abstract}

Citation:

Broshkov, M.M., Trokosi, D.S., Sheviakova, A.A. (2016). Relative indices of immunograms in seropositive on toxoplasma infestation of dogs and cats. Scientific Messenger LNUVMBT named after S.Z. Gzhytskyj, 18, 2(66), 20-23. 


\title{
Relative indices of immunograms in seropositive on toxoplasma infestation of dogs and cats
}

\author{
M.M. Broshkov ${ }^{1}$, D.S. Trokosi ${ }^{2}$, A.A.Sheviakova ${ }^{1}$ \\ dolinavet@gmail.com \\ ${ }^{1}$ Odessa State Agrarian University, \\ Panteleimonovska Str., 3, Odessa 65012, Ukraine \\ ${ }^{2}$ National University of life and environmental sciences of Ukraine, \\ Heroyiv Oborony Str., 11, Kyiv, 03041, Ukraine
}

\begin{abstract}
In most parasitic diseases, the main element of protection of an organism is cell-mediated immunity. His immunological reactivity depends on the ability of an organism to respond adequately to the introduction of antigen. Evaluation of relative indices of the immunogram of HIV-positive dogs and cats have shown that a more pronounced decrease in the relative number of lymphocytes in the experimental group were observed in dogs (33\% of the trial) compared with cats (22\%). This species difference is probably due to the development cycle of the pathogen and the fact, namely, dogs are the ultimate owners unlike cats. Comparing the relative number of T-helper lymphocytes, it should be noted that seropositive dogs, the figure was higher (by 15\% in comparison with the control) and in the middle pozitivnih cats on the contrary marked reduction (47\% compared to control). In experimental dogs, compared with control the ability of neutrophils to phagocytosis is less than $8 \%$ and cats the difference is $1.5 \%$.

When the relative amount by B-lymphocytes in seropositive dogs and cats found that subpopulation of lymphocytes, unlike $T$ cells, in contrast was higher in the experimental group of animals. In the control group of dogs and cats of these cells is within $11 \%$. In the experimental group of cats increased number of these cells is more pronounced and 3.25\% more than in the experimental group of dogs. Analysis of the relative amount of lymphocytes $N K$-showed that the number of these cells is lower in seropositive for toxoplasmosis dogs and cats. A marked reduction of cell found in cats experimental group (by 5.25\%), but in dogs by $1.75 \%$.

Given the slight percentage decrease ability neutrophil phagocytosis can be assumed that this cell population is not exposed to marked reduction due to specific receptors vidsutnistyu toksoplazmenoho antigen and it does not allow pathogens directly affect the functional activity of these cells.
\end{abstract}

Key words: immunity, Toxoplasma, T-lymphocytes, b-lymphocytes, cats, dogs.

\section{Вступ}

Токсоплазмоз - зоонозне протозойне захворювання, спричинене внутрішньоклітинним паразитом Toxoplasma gondii, яке характеризується поліморфізмом клінічних проявів з переважним ураженням нервової, лімфатичної систем, очей, скелетних м язів і міокарда.

Актуальність проблеми токсоплазмозу зумовлена сукупністю взаємозв'язаних чинників мікроорганізму, макроорганізму і довкілля. Контролювати та кардинально впливати на поширення токсоплазмозу важко, оскільки розповсюдження його у природі відбувається в організмі більше 300 видів ссавців і 100 видів птахів, причому людина у цьому участі не бере. За різними даними літератури, інфікованість дорослого населення земної кулі токсоплазмами складає від 30 до $80 \%$, у деяких регіонах наближаючись до $90 \%$ i вище (Lipkovskaja et al., 2013).

Серед домашніх м'ясоїдних тварин, що знаходяться в тісному взаємозв'язку з людиною, серопозитивних на Toxoplasma gondii, реєструється в середньому у 17\% котів та у 13,5\% собак (Esteves et al., 2014).

Відсутністю лабораторного обстеження тварин, води, грунту, їжі в зв'язку з чим практично неможливо виявити джерела інфікування і попередити розвиток захворювання, а також недоліком санітарнопросвітницької роботи та недотриманням правил особистої гігієни жителями регіону (Berezovs'kyj et al., 2014).

Зараження відбувається легко і в більшості випадків захворювання перебігає латентно. Особливо небезпечний токсоплазмоз для людей з імунодефіцитом як первинного, так і вторинного характеру, у тому числі для вагітних, в яких стан природного вторинного імунодефіциту поєднується 3 можливістю безпосере- днього патологічного впливу збудника на плід. Але при цьому залишається дискусійним питання, чи імунодефіцитні стани виникають внаслідок токсоплазмозу або активація токсоплазмозу проявляється через імуносупресію (Lipkovs'ka, 2013).

Метою досліджень було встановлення відносної кількості імунокомпетентних клітин та здатності нейтрофілів до фагоцитозу у серопозитивних на токсоплазмену інвазію собак і котів.

\section{Матеріал і методи досліджень}

Для дослідження використовували стабілізовану периферійну кров безпородних котів ( віком від 1 до 4-x років, $\mathrm{n}=8$ ) та безпородних собак (віком від 1 до 4-x років, $\mathrm{n}=7$ ) які за результатами імуноферментного аналізу були серопозитивними на токсоплазмену інвазію. Контролем слугували клінічно здорові коти $(\mathrm{n}=8)$ та собаки $(\mathrm{n}=7)$ тієї ж вікової категорії і $\epsilon$ серонегативними на токсоплазмену інвазію. В крові дослідних тварин визначали абсолютну кількість лейкоцитів (за методикою Дегтяренко Т. В.) абсолютну і відносну кількість лімфоцитів та їх імунорегуляторних субпопуляцій (в реакції розеткоутворення 3 еритроцитами барана) а також фагоцитарну активність нейтрофілів і здатність цих клітин до розеткоутворення (Degtjarenko and Makul'kin, 1997).

\section{Результати та їх обговорення}

В таблиці представлені відносні показники лімфоцитів та їх Т-регуляторних субпопуляцій у серопозитивних і серонегативних на токсоплазмену інвазію котів і собак. 
Характер відмінностей в лімфоцитах у серопозитивних собак і котів в порівнянні с контрольними групами свідчить про значене зменшення кількості імунорегуляторних клітин.

Більш виражене зменшення відносної кількості лімфоцитів в дослідній групі, відмічено у собак (на $33 \%$ в дослідній) в порівняні з котами (на 22\%). Така видова відмінність можливо пов'язана $з$ циклом розвитку самого збудника і тим, а саме, собаки є кінцевими господарями на відміну від котів. Порівнюючи відносну кількість Т-хелперних лімфоцитів, слід за- значити, що у серопозитивних собак цей показник був вищим (на 15\% в порівнянні з контролем) а у сер опозитивних котів навпаки відмічено його зменшення (на 47\% в порівнянні з контролем). В сучасній науковій літературі відсутні публікації і тлумачення таких видових відмінностей в стані клітинного імунітету тому це потребує більш детального дослідження. Однакова реакція з боку Т- супресорних лімфоцитів відзначається в дослідних групах собак і котів, а саме зменшення відносної кількості цих клітин в порівнянні з контрольною групою тварин.

Табличя 1

Відносні показники лімфоцитів у сер опозитивних собак і котів

\begin{tabular}{|l|c|c|c|c|}
\hline \multirow{2}{*}{ Показники } & \multicolumn{2}{|c|}{ Собаки } & \multicolumn{2}{c|}{ Коти } \\
\cline { 2 - 5 } & Дослідна група & Контрольна група & Дослідна група & Контрольна група \\
\hline Лімфоцити, \% & $21,75 \pm 2,217$ & $28,0 \pm 2,193$ & $26,7 \pm 8,5$ & $33,25 \pm 7,9$ \\
\hline Т-лімфоцити, \% & $60,5 \pm 7,317$ & $73,0 \pm 2,0$ & $54,5 \pm 8,358$ & $71,0 \pm 6,831$ \\
\hline T-хелпери, \% & $59,0 \pm 2,0$ & $50,5 \pm 7,188$ & $34,5 \pm 6,603$ & $51,0 \pm 12,055$ \\
\hline T-супресори, \% & $16,0 \pm 1,633$ & $22,5 \pm 3,188$ & $17,0 \pm 3,464$ & $21,0 \pm 2,055$ \\
\hline
\end{tabular}

Примітка. ${ }^{*} \mathrm{p}<0,01$ порівняно між контрольною і дослідною групами в межах виду

При визначені відносної кількості В-лімфоцитів (рис. 1) у сер опозитивних собак і котів встановлено, що субпопуляція лімфоцитів, на відміну від Тлімфоцитів, навпаки була вищою у тварин дослідної групи. В контрольній групі собак і котів кількість цих клітин знаходилась в межах 11\%. В дослідної групи котів збільшення кількості цих клітин більш виражене і на 3,25\% більше ніж у собак дослідної групи.

Оскільки популяція цих клітин має пряме відношення до гуморальної ланки імунітету можна припустити те, що це компенсаторна реакція організму у відповідь на супресію клітинної ланки імунітету (Novikov et al., 2005).

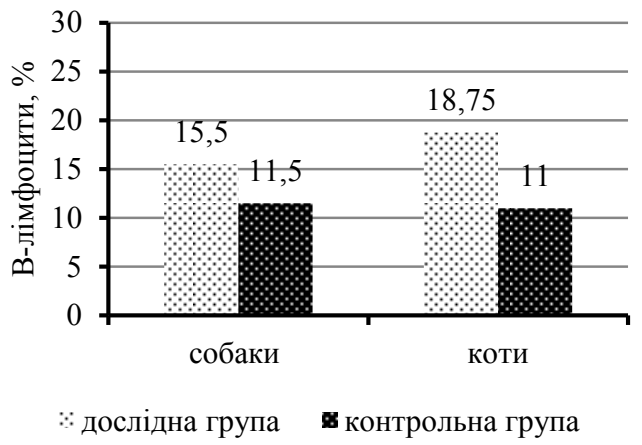

Рис. 1. Відносна кількість В-лімфоцитів у серопозитивних на токсоплазмоз собак і котів

Враховуючи той факт, що ми достовірно не знаємо термін персистенції токсоплазменого антигену в організмі дослідних тварин слід врахувати що термін від зараження до безпосереднього виявлення антитіл також впливає на перебудову в імунному статусі заражених тварин (Dubey et al., 2006).

Аналіз відносної кількості NK-лімфоцитів (рис. 2) показав, що кількість цих клітин є меншою у серопозитивних на токсоплазмоз собак і котів. Більш виражене зменшення цих клітин встановлено у котів дослідної групи (на 5,25\%) проте у собак на 1,75\%.
В минулих наукових працях нами було показано, зв'язок між імунофізіологічним статусом і ступенем сенсибілізації Т-«активних» лімфоцитів до нейроантигенів сітківки ока. При цьому було доведено, що фізіологічно адекватними є зміни імунореактивності, характерні для різного ступеня аутосенсибілізації організму собак до нейроантигенів сітківки ока. При аутосенсібілізації (за відсотком інверсії) до нейроантигенів сітківки ока $10 \%$ абсолютна кількість лейкоцитів збільшується на, а абсолютна кількість лімфоцитів зменшується (Broshkov, 2016).

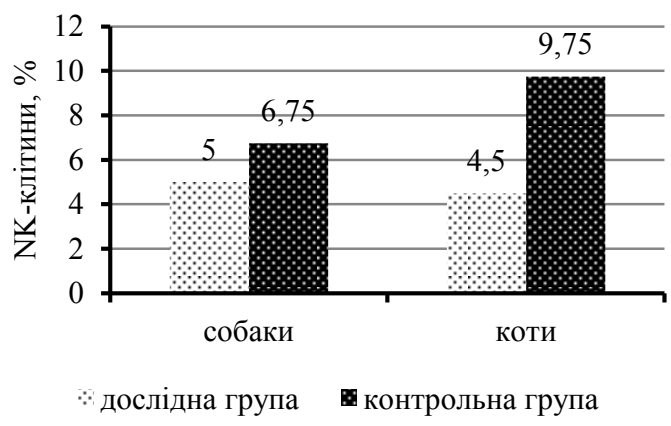

Рис. 2. Відносна кількість NK-лімфоцитів у серопозитивних на токсоплазмоз собак і котів

Аналіз отриманих нами результатів показав (рис. 3), що у серопозитивних собак і котів (дослідні групи) цей показник був нижчим. При цьому більш виражене зменшення ступеня сенсибілізації було у котів (на $8,5 \%$ ) проти собак (на 5\%). Зазвичай збільшення ступеня сенсибілізації Т-«активних» лімфоцитів до антигенів відбувається при збільшенні цього антигену в крові (Broshkov, 2016). Враховуючи те, що при токсоплазменій інвазії відбулося зменшення ступеня сенсибілізації до нейроантигенів сітківки ока можна припустити, що сам збудник не викликає руйнування структур нервової системи а неврологічні прояви у серопозитивних на токсоплазмоз собак і котів пов'язані зі супутніми інфекціями або неврологічні явища пов'язані з порушеннями синтезу нейромедіаторів (Frolov, 1999). 


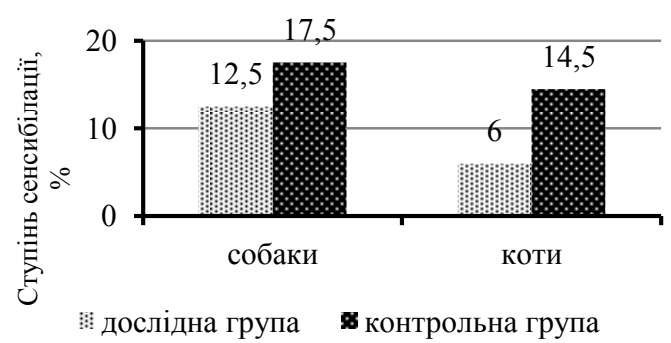

Рис. 3. Ступінь сенсибілізації T-«активних» лімфоцитів до нейроантигенів сітківки ока

Окрім лімфоцитів важливу участь в імунній відповіді відіграють і гранулярні лейкоцити, а саме нейтрофілів. Основним критерієм оцінки їх фізіологічної активності є здатність до фагоцитозу. Фагоцитарна активність нейтрофілів у дослідних собак дещо відрізнялась від дослідних котів (Рис 4.). У дослідних собак порівняно 3 контролем здатність нейтрофілів до фагоцитозу менше на $8 \%$ а котів різниця складає $1,5 \%$.

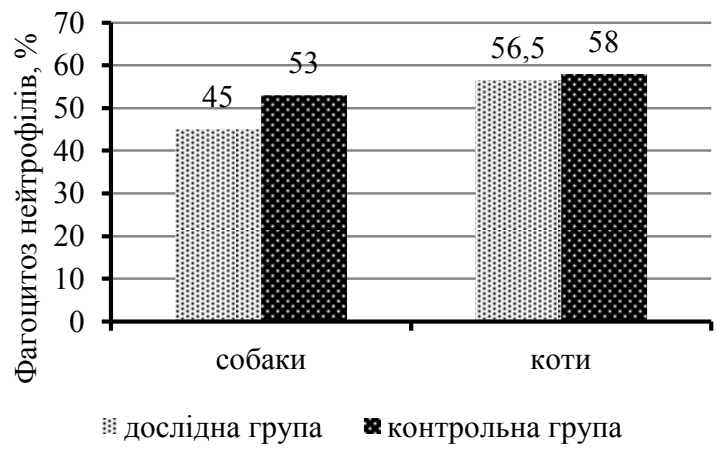

Рис. 4. Фагоцитарна активність нейтрофілів у серопозитивних на токсоплазмоз собак і котів

Враховуючи незначне відсоткове зменшення здатності нейтрофілів до фагоцитозу можна припустити, що ця популяція клітин не піддається вираженому зменшенню в зв'язку зі відсутністью специфічних рецепторів до токсоплазменого антигену і це не дає можливість збуднику прямо впливати на функціональну активність цих клітин (Novikov et al., 2005; Coelho et al., 2014).

Отже отримані матеріали дослідження щодо особливостей імунофізіологічного статусу у серопозитивних собак і котів необхідно враховувати для проведення більш ефективнішої та орієнтувальної імунокорекції в протоколах терапії.

\section{Висновки}

1.Встановлено, що серопозивних на $T$. gondii собак і котів відносна кількість Т-лімфоцитів та їх імунорегуляторних субпопуляцій значно знижена. Більш виражено імуносупресія проявляється у котів ніж у собак.

2. Показано, що на відміну від Т-лімфоцитів відносна кількість В-лімфоцитів навпаки у серопозивних на $T$. gondii собак і котів більша ніж у серонегативних.
Таке явище можна пояснити компенсаторною реакцією гуморальної ланки імунітету організму у відповідь на супресію клітинної ланки.

\section{Бібліографічні посилання}

Berezovs'kyj, A.V., Jakubchak, O.M., Galat, V.F. (2014). Diagnostyka toksoplazmozu tvaryn. Naukovotehnichnyj bjuleten' In-tu biologii' tvaryn i Derzhavnogo naukovo-doslidnogo kontr. in-tu vetpreparativ ta kormovyh dobavok. 15(1), 221-225 (in Ukrainian).

Broshkov, M.M. (2016). Imunnyj status organizmu sobak zalezhno vid fiziologichnyh osoblyvostej i jogo korekcija. Avtoref. dys. ... d-ra vet. nauk, spec. 03.00.13. K.: NUBiP Ukrai'ny. 40 (in Ukrainian).

Degtjarenko, T.V., Makul'kin R.F. (1997). Biogennye stimuljatory i immunoreaktivnost'. O.: Majak. 1, 5273 (in Russian).

Lipkovskaja, I.V., Marichereda, V.G., Chueva, T.P. (2013). Osobennosti diagnostiki toksoplazmoznoj infekcii $\mathrm{u}$ beremennyh $\mathrm{v}$ Odesskom regione $\mathrm{v}$ sootvetstvii so standartami VOZ i MKB 10. Imunologija ta alergologija. 3, 57-65 (in Russian).

Lipkovs'ka, I.V. (2013). Kliniko-laboratorna harakterystyka gostroi' stadii' nabutogo toksoplazmozu. Infekc. hvoroby: naukovo-praktychnyj medychnyj zhurnal. 2, 45-53 (in Ukrainian).

Novikov, P.D. Konevalova, N.Ju., Titova, N.D. (2005). Principy ocenki immunnogo statusa i diagnostiki dinamike novoobrazovanija i migracii aktivirovannyh limfocitov vo immunodeficitnyh boleznej. Immunopatologija, allergologija, infektologija. 2, 822 (in Russian).

Senchilo, I.V. (1991). Reakcija aktivnogo rozetkoobrazovanija kak metod ocenki funkcii Tlimfocitov $\mathrm{v}$ klinicheskoj praktike. Terapevticheskij arhiv. 63(7), 135-138 (in Russian).

Frolov, A.K. (1999). Patogeneticheskij analiz sostojanija immunnoj sistemy po vnutrennej srede organizma: metod. Rekomendacii. Zaporozh'e: ZGU. (in Russian).

Coelho, C., Vieira-Pinto, M., Faria., A.S., ValeGoncalves, H., Veloso, O., Paiva-Cardoso, M.N., Mesquita, J.R., Lopes, A.P. (2014). Serological evidence of Toxoplasma gondii in hunted wild boar from Portugal. Veterinary Parasitology. 202, 310-312.

Dubey, J.P., Vianna, M.C., Sousa, S., Canada, N., Meireles, S., Correia da Costa, J.M., Marcet, P.L., Lehmann, T., Dardé, M.L., Thulliez, P. (2006). Characterization of Toxoplasma gondii isolates in free-range chickens from Portugal. Journal of Parasitology. 92, 184-186.

Esteves, F., Aguiar, D., Rosado, J., Costa, M. L., de Sousa, B., Antunes, F., Matos, O. (2014). Toxoplasma gondii prevalence in cats from Lisbon and in pigs from centre and south of Portugal. Veterinary Parasitology. 200, 8-12.

Стаття надійшла до редакиії 23.09.2016 